\title{
HIPERTENSIUNEA ARTERIALĂ SECUNDARĂ ÎN INTOXICAȚIILE ACUTE LA COPIL ŞI ADOLESCENT
}

\author{
Asist. Univ. Dr. Cristina Iolanda Vivisenco, Prof. Dr. Coriolan Emil Ulmeanu \\ Spitalul Clinic de Urgență pentru Copii ,, Grigore Alexandrescu“, Bucureşti \\ Catedra Pediatrie, Universitatea de Medicină şi Farmacie „, Carol Davila “, Bucureşti
}

\begin{abstract}
REZUMAT
Introducere. Expunerea la diverse medicamente cardiovasculare şi non-cardiovasculare, substanțe de abuz, substanțe chimice sau porțiuni de plante poate genera hipertensiune arterială secundară. Autorii raportează experiența personală legată de hipertensiunea arterială secundară intoxicațiilor acute la copil şi adolescent. Material şi metodă. Am condus un studiu prospectiv pe o perioadă de 24 de luni în care am inclus 151 de copii şi adolescenți cu afectare toxică cardiovasculară. Pentru depistarea cazurilor de hipertensiune arterială secundară, semnele vitale au fost analizate la internare şi în dinamică ținând cont de valorile normale pentru vârstă.

Rezultate. $11,1 \%$ din totalul cazurilor de intoxicație acută internate şi tratate în departamentul nostru au asociat afectare toxică cardiovasculară. Dintre acestea, $18,5 \%$ au fost cazuri de hipertensiune arterială secundară. Principala cauză a hipertensiunii arteriale în lotul studiat a fost expunerea la insecticide organofosforice, urmată de expunerea la medicamente simpatomimetice. În cazul insecticidelor organofosforice am constatat un comportament dual. Pacienții au prezentat la debutul intoxicației o scurtă perioadă de tahicardie şi hipertensiune arterială, ulterior instalându-se tabloul colinergic clasic din intoxicația acută cu insecticide organofosforice, cu bradicardie şi/sau hipotensiune arterială. Toate cazurile de hipertensiune arterială identificate au fost creşteri tranzitorii, autolimitate ale valorilor tensiunii arteriale, ce nu au necesitat asocierea agenților hipotensori în abordarea terapeutică.

Concluzii. Intoxicațiile acute ale copilului şi adolescentului se pot complica cu hipertensiune arterială, cel mai adesea uşoară şi tranzitorie. Monitorizarea semnelor vitale este esențială pentru abordarea acestor cazuri. Personalul medical trebuie să cunoască temeinic particularitățile legate de vârstă, inclusiv intervalele de referință pentru valorile tensiunii arteriale la copil şi adolescent.
\end{abstract}

Cuvinte cheie: hipertensiune arterială secundară, intoxicație acută, insecticide organofosforice, copil, adolescent

\section{INTRODUCERE}

Tensiunea arterială este un parametru vital ce se corelează în mod direct cu frecvența cardiacă, volumul bătaie şi rezistența vasculară sistemică. Menținerea sa în limite normale este dependentă de buna funcționare a cordului şi vaselor. Componenta sistolică reflectă funcția inotropă a miocardului, în timp ce componenta diastolică reflectă tonusul vascular $(1,2)$.

Creşterea valorilor tensiunii arteriale datorită unei cauze subiacente ce poate fi identificată şi cel mai adesea corectată, defineşte hipertensiunea arterială secundară. Expunerea la diverse medicamente cardiovasculare şi noncardiovasculare, substanțe de abuz, substanțe chimice sau porțiuni de plante poate genera hipertensiune arterială secundară $(3,4)$. În acest studiu, raportăm experiența clinicii noastre legată de afectarea toxică cardiovasculară şi hipertensiunea arterială secundară intoxicațiilor acute la copil şi adolescent.

\section{MATERIAL ŞI METODĂ}

În perioada octombrie 2011-septembrie 2013, am realizat în Secția de Toxicologie - Terapie Intensivă a Spitalului Clinic de Urgență pentru Copii „Grigore Alexandrescu“ din Bucureşti un

Adresa de corespondență:

Asist. Univ. Dr. Iolanda Cristina Vivisenco, Spitalul Clinic de Urgență pentru Copii „Grigore Alexandrescu“, Bd. lancu de Hunedoara nr. 30-32, sector 1, Bucureşti

E-mail: iolanda.vivisenco@gmail.com 
studiu prospectiv, observațional şi descriptiv în care am inclus un lot de 151 de pacienți cu vârsta cuprinsă între 0 şi 18 ani, internați cu diagnosticul de intoxicație acută, care au asociat de la prezentare sau în evoluție afectare cardiovasculară. Demonstrarea afectării cardiovasculare a presupus identificarea cel puțin a uneia dintre următoarele manifestări: tulburări de ritm şi de conducere, anomalii ale tensiunii arteriale, sindroame coronariene acute, insuficiență cardiacă congestivă, şoc cardiogenic şi/sau vasoplegic. Au fost excluşi din studiu pacienții cunoscuți cu boală cardiacă anterior expunerii toxice şi cei care, deşi internaţi pentru intoxicație acută cu agenți cu potențial cardiotrop şi/sau vasculotrop, nu au dezvoltat afectare cardiovasculară. Pentru realizarea acestui studiu a fost solicitat şi obținut avizul comisiei de etică din cadrul spitalului.

Pentru depistarea cazurilor de hipertensiune arterială secundară, semnele vitale au fost analizate la internare şi în dinamică ținând cont de valorile normale pentru vârstă. Tensiunea arterială a fost măsurată cu manşete de dimensiuni adecvate prin me- toda oscilometrică utilizând monitoare Dinamap. Pentru analiza valorilor obținute la grupa de vârstă 0-5 ani am utilizat graficele publicate de Park şi colaboratorii în 1989, iar pentru copiii mai mari de 5 ani am folosit graficele publicate de acelaşi colectiv în $2005(5,6)$. Am considerat anormale valorile situate sub percentila 5 şi, respectiv, peste percentila 95 .

\section{REZULTATE}

În cele 24 de luni studiate, în secția noastră au fost internate şi tratate 1.358 de cazuri de intoxicație acută. Dintre acestea, am inclus în studiul personal un număr de 151 de cazuri care au prezentat la internare sau pe parcursul spitalizării afectare cardiovasculară, prevalența acestora fiind de $11,1 \%$. În Tabelul 1 este prezentată etiologia intoxicațiilor acute din lotul studiat.

În Tabelul 2 am sintetizat datele obținute prin monitorizarea tensiunii arteriale la pacienții din lotul studiat. Hipertensiunea arterială a fost înregistrată în 28 de cazuri, ceea ce reprezintă $18,5 \%$

TABELUL 1. Etiologia intoxicațiilor în lotul studiat

\begin{tabular}{|c|c|c|}
\hline Etiologie & $\begin{array}{c}\text { Număr de } \\
\text { cazuri }\end{array}$ & Procent \\
\hline \multicolumn{3}{|l|}{ Medicamente } \\
\hline Glicozide digitalice: digoxin & 1 & 0,66 \\
\hline$\beta$-blocante: metoprolol, bisoprolol, carvedilol, Distonocalm & 10 & 6,62 \\
\hline$\alpha_{2}$-agoniști centrali: clonidină, moxonidină & 4 & 2,65 \\
\hline Blocante de calciu: diltiazem, nifedipină & 2 & 1,32 \\
\hline Antiaritmice blocante ale canalelor de sodiu: propafenonă & 1 & 0,66 \\
\hline Nitrați: tetranitrat de pentaeritril & 1 & 0,66 \\
\hline Antidepresive triciclice: amitriptilină, clomipramină, imipramină & 4 & 2,65 \\
\hline Antidepresive serotoninergice: tianeptină, venlafaxină, escitalopram & 3 & 1,99 \\
\hline Neuroleptice: haloperidol, risperidonă, olanzapină, quetiapină, aripiprazol & 8 & 5,3 \\
\hline Anticonvulsivante: carbamazepină, valproat, oxcarbazepină & 22 & 14,57 \\
\hline Agoniști dopaminergici: bromocriptină & 1 & 0,66 \\
\hline Simpatomimetice: adrenalină, salbutamol, fenilefrină & 21 & 13,91 \\
\hline Decongestionante nazale: nafazolină \pm efedrină, trimazolină + fenilefrină & 4 & 2,65 \\
\hline Metilxantine: teofilină & 3 & 1,99 \\
\hline Miorelaxante centrale: baclofen & 1 & 0,66 \\
\hline Antimalarice: mefloquină+artesunat & 1 & 0,66 \\
\hline Anestezice locale: lidocaină & 1 & 0,66 \\
\hline Hormoni tiroidieni: levotiroxină & 2 & 1,32 \\
\hline Intoxicații plurimedicamentoase & 22 & 14,57 \\
\hline Substanțe de abuz & 8 & 5,3 \\
\hline Substanțe anabolizante & 1 & 0,66 \\
\hline \multicolumn{3}{|l|}{ Toxice rurale } \\
\hline Insecticide inhibitorii de colinesterază (organofosforate) & 12 & 7,95 \\
\hline Nitriți (apă de puț) & 7 & 4,64 \\
\hline \multicolumn{3}{|l|}{ Toxice menajere } \\
\hline Monoxid de carbon & 11 & 7,28 \\
\hline Total & 151 & 100 \\
\hline
\end{tabular}


din totalitatea cazurilor cu afectare cardiovasculară de cauză toxică. În 5 cazuri, pacienții au prezentat la debutul intoxicației acute hipertensiune arterială tranzitorie, urmată de instalarea hipotensiunii arteriale. Toate cazurile de hipertensiune arterială identificate în studiul personal au fost creşteri tranzitorii, autolimitate ale valorilor tensiunii arteriale. Monitorizarea continuă a semnelor vitale a arătat revenirea spontană la valori normale a tensiunii arteriale, fără a fi necesară asocierea agenților hipotensori în abordarea terapeutică a acestor pacienți.

TABELUL 2. Tensiunea arterială - valori în lotul studiat

\begin{tabular}{|l|c|}
\hline Tensiune arterială & $\mathbf{n}(\%)$ \\
\hline Scăzută & $24(15,89)$ \\
\hline Normală & $99(65,56)$ \\
\hline Crescută & $23(15,23)$ \\
\hline Scăzută + Crescută & $5(3,31)$ \\
\hline Total & $151(100)$ \\
\hline
\end{tabular}

Etiologia hipertensiunii arteriale în lotul analizat este sintetizată în Tabelul 3. Principala cauză a hipertensiunii arteriale a fost expunerea la insecticide organofosforice, urmată de expunerea la medicamente simpatomimetice.

TABELUL 3. Etiologia hipertensiunii arteriale în lotul studiat

\begin{tabular}{|l|c|}
\hline & $\begin{array}{c}\text { Număr } \\
\text { cazuri }\end{array}$ \\
\hline$\alpha_{\text {,-agoniști centrali: clonidină }}$ & 1 \\
\hline Antidepresive serotoninergice: venlafaxină & 1 \\
\hline Neuroleptice: risperidonă, aripiprazol & 2 \\
\hline Anticonvulsivante: carbamazepină & 3 \\
\hline Simpatomimetice: salbutamol, adrenalină, fenilefrină & 5 \\
\hline Decongestionante imidazolinice & 2 \\
\hline Miorelaxante centrale: baclofen & 1 \\
\hline Anestezice locale: lidocaină & 1 \\
\hline Ingestii plurimedicamentoase & 3 \\
\hline Amfetamine & 1 \\
\hline Anabolizante & 1 \\
\hline Insecticide organofosforice & 7 \\
\hline Total & 28 \\
\hline
\end{tabular}

Insecticidul organofosforic identificat în cele 7 cazuri a fost diazinonul. Cei cinci pacienți la care am observat pe parcursul evoluției atât perioade de hipertensiune, cât şi hipotensiune arterială au fost cazuri de intoxicație acută cu diazinon. Aceştia au prezentat la debutul intoxicației o scurtă perioadă de tahicardie şi hipertensiune arterială, ulterior instalându-se tabloul colinergic clasic din intoxicația acută cu insecticide organofosforice, cu bradicardie şi/sau hipotensiune arterială.

Două treimi $(n=19)$ din cazurile de hipertensiune arterială secundară au fost cauzate de agenți far- macologici, singuri sau în asociere. Într-un caz de intoxicație acută cu clonidină pacientul a prezentat la debutul intoxicației un episod tranzitor de hipertensiune arterială. Celelalte cazuri de intoxicații medicamentoase ce au asociat hipertensiune arterială au fost cauzate de agenți farmacologici noncardiovasculari. Dintre aceştia, aşa cum am menționat mai sus, primul loc a fost ocupat de medicamentele simpatomimetice. Expunerea la simpatomimetice a fost accidentală în toate cazurile, prin ingestia soluțiilor de uz intranazal, oral sau inhalator de către copiii mici sau prin administrarea de către aparținători în nebulizator a unor doze greşite de adrenalină şi, respectiv, salbutamol. O modalitate similară de expunere toxică am observat şi în cazul decongestionantelor nazale pe bază de agenți imidazolinici, singuri sau în asociere cu simpatomimetice. Astfel, am constatat hipertensiune arterială în 2 cazuri de ingestie şi, respectiv, administrare accidentală intranazală a unor doze toxice de nafazolină \pm efedrină.

Am constatat hipertensiune arterială într-un număr semnificativ de cazuri de expunere la medicamente cu acțiune farmacologică asupra sistemului nervos central: anticonvulsivante, antidepresive triciclice şi serotoninergice, neuroleptice. 3 dintre aceste cazuri au fost coingestii medicamentoase: carbamazepină + paroxetină + diazepam, valproat + amitriptilină şi, respectiv, tianeptină + amitriptilină.

\section{DISCUȚII}

Monitorizarea semnelor vitale reprezintă o etapă esențială în abordarea diagnostică a pacienților cu intoxicaţie acută. Tensiunea arterială poate fi modificată de numeroase substanțe toxice care, odată absorbite în organism, interacționează cu procesele chimice ce se desfăşoară în mod normal în terminațiile fibrelor simpatice postganglionare de la nivelul muşchiului neted vascular şi cardiac $(1,7)$. Cele două mecanisme esenţiale prin care apare hipertensiunea arterială la pacienții intoxicați sunt creşterea rezistenței vasculare şi/sau creşterea inotropismului. Vasoconstricția este implicată cel mai frecvent în apariția hipertensiunii arteriale de cauză toxică şi se produce prin stimularea receptorilor $\alpha 1$ adrenergici. Stimularea receptorilor $\beta 1$-adrenergici creşte contractilitatea miocardică $(1,3,7)$. Majoritatea toxicelor (ex. amfetamine, adrenalină, fenilefrină, efedrină) generează o activare difuză a receptorilor adrenergici prin creşterea eliberării de catecolamine sau inhibarea recaptării şi degradării acestora. Domină însă efectele $\alpha 1$ şi $\beta 1$, care vor genera hipertensiunea arterială specifică toxidromului simpatomimetic $(1,3,8)$. 
La pacientul intoxicat trebuie evaluate atât componenta sistolică, cât şi cea diastolică a tensiunii arteriale. Agoniştii receptorilor $\alpha 1$-adrenergici vor crește ambele componente presionale, în timp ce agoniştii neselectivi $\beta$-adrenergici pot genera o creștere a presiunii arteriale diferențiale. Aceasta se explică prin creşterea tensiunii arteriale sistolice ca urmare a stimulării receptorilor $\beta 1$-adrenergici şi scăderea tensiunii arteriale diastolice ca efect al vasodilatației mediate prin receptorii $\beta 2$-adrenergici. Deoarece receptorii $\beta 1$-adrenergici cresc contractilitatea şi frecvența cardiacă, iar cei $\beta 2$-adrenergici fac vasodilatație, numai substanțele care acționează predominant pe subtipul $\beta 1$ ar genera hipertensiune arterială. În supradoze însă, specificitatea nu se mai menține şi agoniştii $\beta 2$-adrenergici pot creşte inotropismul şi cronotropismul (9-11). Am constatat acest lucru în studiul personal, în cazul celor 3 pacienţi expuşi la doze toxice de salbutamol.

În studiu am identificat şi un caz de hipertensiune arterială tranzitorie secundară intoxicației acute cu clonidină. În doze terapeutice, aceasta stimulează receptorii $\alpha 2$-adrenergici centrali, exercitând efecte antihipertensive şi sedative $(1,12)$. Dozele toxice de clonidină stimulează însă şi receptorii $\alpha 2$-adrenergici periferici, cu eliberare de noradrenalină, vasoconstricție şi hipertensiune arterială. Acest efect paradoxal asupra tensiunii arteriale este de scurtă durată, fiind inhibat de efectele centrale, mult mai potente $(13,14)$. Pornind de la molecula de clonidină au fost sintetizate o serie de derivate imidazolinice (nafazolină, oximetazolină, xilometazolină), utilizate ca decongestionante nazale sau oculare. Aceste preparate sunt întâlnite frecvent în intoxicațiile acute ale copilului, provocând, din cauza toxicității similare agoniștilor $\alpha 2$-adrenergici centrali, depresie marcată a sistemului nervos central, insuficiență respiratorie şi afectare cardiovasculară $(15,16)$. În studiul personal am întâlnit 2 astfel de cazuri, ambele fiind intoxicații acute accidentale cu nafazolină.

Foarte interesantă este constatarea mecanismului de acțiune dual pe care îl posedă insecticidele inhibitori de colinesterază. Aceste toxice prezintă atât activitate simpatică, cât şi parasimpatică, ceea ce explică modificările observate la pacienții din studiu. Efectele cardiovasculare sunt imprevizibile şi adesea se modifică în evoluția intoxicației. La debut, acetilcolina stimulează receptorii nicotinici din neuronii ganglionari simpatici, conducând la tahicardie şi hipertensiune uşoară. Ulterior se instalează toxidromul colinergic clasic cu bradicardie şi hipotensiune, prin stimularea receptorilor muscarinici sau blocarea transmiterii ganglionare prin hiperpolarizare (17-19).

În general, hipertensiunea arterială secundară din intoxicațiile acute este uşoară şi tranzitorie, în literatură fiind rar descrise cazuri de hipertensiune arterială severă de cauză toxică, complicată cu encefalopatie, accident vascular cerebral sau insuficiență renală ireversibilă $(20,21)$. În absența unui ghid specific de tratament al hipertensiunii arteriale de cauză toxică, tratamentul antihipertensiv iniţial are ca scop neutralizarea mecanismului toxic subiacent (22). În lotul studiat creşterea valorilor tensionale a fost tranzitorie în toate cazurile şi nu a necesitat intervenție terapeutică cu agenți farmacologici hipotensori.

\section{CONCLUZII}

Intoxicațiile acute ale copilului şi adolescentului se pot complica cu hipertensiune arterială, cel mai adesea uşoară şi tranzitorie. Agenții etiologici implicați sunt foarte variați, de la medicamente din clasele farmacologice cardiovasculare şi mai ales noncardiovasculare, până la substanțe de abuz sau insecticide. Chiar şi unele medicamente antihipertensive pot determina în doză toxică hipertensiune arterială paradoxală. Monitorizarea semnelor vitale atât la prezentare, cât şi în dinamică, este esențială pentru abordarea cazurilor de intoxicație acută. Personalul medical care gestionează această patologie la copil şi adolescent trebuie să cunoască temeinic particularitățile legate de vârstă, inclusiv intervalele de referință pentru valorile tensiunii arteriale. 